Article

\title{
Experiential Value of Exhibition in the Cultural and Creative Park: Antecedents and Effects on CCP Experiential Value and Behavior Intentions
}

\author{
Haimeng Ding ${ }^{1,2}, *$, Kuang-Peng Hung ${ }^{2}$, Norman Peng ${ }^{3}$ and Annie Chen ${ }^{4}$ \\ 1 College of Creative Culture and Communication, Zhejiang Normal University, Jinhua 321004, China \\ 2 Department of Business Administration, Ming Chuan University, Taipei 111, Taiwan; \\ kphung@mail.mcu.edu.tw \\ 3 Glasgow School for Business and Society, Glasgow Caledonian University, Glasgow G4 0BA, UK; \\ norman.peng@gcu.ac.uk \\ 4 Roehampton Business School, Roehampton University, London SW15 5PJ, UK; annie.chen@roehampton.ac.uk \\ * Correspondence: dhm@zjnu.edu.cn
}

Citation: Ding, H.; Hung, K.-P.; Peng, N.; Chen, A. Experiential Value of Exhibition in the Cultural and Creative Park: Antecedents and Effects on CCP Experiential Value and Behavior Intentions.

Sustainability 2021, 13, 7100

https://doi.org/10.3390/su13137100

Academic Editor: Andrea Pérez

Received: 5 June 2021

Accepted: 22 June 2021

Published: 24 June 2021

Publisher's Note: MDPI stays neutral with regard to jurisdictional claims in published maps and institutional affiliations.

Copyright: (C) 2021 by the authors. Licensee MDPI, Basel, Switzerland. This article is an open access article distributed under the terms and conditions of the Creative Commons Attribution (CC BY) license (https:/ / creativecommons.org/licenses/by/ $4.0 /)$.

\begin{abstract}
The protection of industrial cultural heritage is related to sustainable urban development. Cultural and creative parks (CCPs) are a way for many cities to protect their industrial cultural heritage. In the context of CCPs, this study examines the relationships among the antecedents of exhibition experiential value, CCP experiential value, and behavioral intentions. Surveying 428 visitors in two well-known CCPs in Taipei, this study found that the four antecedents (attractiveness, existential authenticity, self-congruence, and exhibition-park image congruence) have a positive impact on exhibition experiential value. Exhibition experiential value has a positive impact on CCP experiential value, which in turn, affects behavioral intentions toward the CCP. In addition, this study finds that exhibition experiential value has a mediating effect between the four antecedents and CCP experiential value. Moreover, CCP experiential value has a mediating effect between exhibition experiential value and behavioral intentions. The findings of this study provide a direction for CCPs to achieve sustainable development through exhibitions that can attract more tourists.
\end{abstract}

Keywords: cultural and creative parks; experiential value; attractiveness; existential authenticity; self-congruence; exhibition-park image congruence; behavioral intentions

\section{Introduction}

As the post-industrial economy comes of age, how to protect industrial cultural heritage is one of the problems faced by many cities to achieve sustainable development [1]. Many cities worldwide are contemplating retaining existing industrial sites and transforming them into visitor attractions with a brand positioning in culture and creativity [2-5]. For example, the Sheffield Cultural Industries Quarter (CIQ) in England and the Huashan 1914 Creative Park in Taipei, Taiwan, which were once abandoned factories, have enhanced creative cultivation through the regeneration and rejuvenation of their cultural heritages. These cultural and creative parks (CCPs) have become a type of cultural and creative tourist attractions [6-8] that provide visitors with cultural and creative experiences by adding creative elements and content on the basis of cultural experience [4]. Such an ambiance of diversity and creativity gives rise to an experiential economy that attracts a large number of visitors and that boosts the vitality of the local economy [7]. As a way of sustainable tourism development, cultural and creative parks have developed rapidly in many cities.

In order to realize the sustainable development of CCPs, scholars have carried out research on CCPs from different perspectives over the last two decades [8]. For example, Chen and Chou [5] examined the factors that affect the "cool" experience of Generation $Y$ consumers in the park. Hung et al. [7] studied the experiential value of CCPs, which has a positive effect on visitors' satisfaction with these parks. Prior research is centered on 
visitors' overall experience in the CCPs [8-10], but there is a lack of research on the impact of exhibitions held in park on the visitors' CCP experiential value.

Exhibitions at CCPs provide cultural and creative tourism and sustainability $[4,11]$. CCPs organize various exhibitions as a key development strategy to offer innovative products and services. Take Huashan1914 as an example: every month, the park offers various types of exhibitions, such as art exhibition, intellectual property exhibitions, and commercial brand exhibitions. Due to the lack of research to explore the impact of exhibitions held by CCPs on the visitors' experiential value of the parks, this research attempts to address the following research gap: does the experiential value of the exhibition in CCPs enhances visitors' CCP experiential value and their behavioral intentions toward the park?

Moreover, the study addresses the second gap, concerning which exhibition-related factors have an impact on the experiential value of the exhibition in CCPs. In the existing literature, the current discussion on exhibitions is mainly related to major trade exhibitions, exhibitions in museums, or specific art exhibitions held in art galleries [12-14]; most studies are conducted from the participants' perspective in an attempt to explore the behavior of participants in exhibitions, the impact factors of the exhibitions, and the relationship between exhibition experiential value and satisfaction [12,14-16], but few studies have examined the factors that influence the visitors' exhibition experiential value held in CCPs. Nevertheless, past research might be able to provide some clues. Some scholars have pointed out that visitors' experiential value for attending exhibitions can be affected by the dimensions of exhibition characteristics, visitors' characteristics, and the exhibition-related context $[16,17]$. Based on the dimensions mentioned above, this study chooses the factors that may affect visitors' exhibition experiential value held in CCPs, which include exhibition characteristics (i.e., attractiveness, existential authenticity), visitors' characteristics (i.e., selfcongruity), and exhibition-park image fit (i.e., image congruence) $[15,16]$. The factors employed in this study are all empirically verified in tourism research. For example, in the study of ecotourism, the attractiveness of destination helps to improve the visitors' experiential value [18]. A study of a luxury spa found that consumers' perception of existential authenticity affects their experiential value [19]. Consumers' self-congruity has an effect on their perceived experiential value [20]. In many studies, scholars point out that image congruence is an important variable affecting consumer experience [21-23].

Given the discussion above, this research adopts the Mehrabian and Russell (MR) model and experiential value theory to construct a research model to achieve the study objectives: First, it aims to explore what exhibition-related factors can affect the experiential value of the exhibitions held in the CCP. Second, it aims to examine how exhibition experiential value impacts CCP experiential value and visitors' behavioral intentions toward the CCP.

This study makes the following theoretical and practical contributions. In terms of theoretical contributions: first, the effects of attractiveness, existential authenticity, selfcongruence, and exhibition-park image congruence on exhibition experiential value are confirmed, which further improve our understanding of the critical successful factors in organizing exhibitions, enriching the content of cultural and creative tourism in CCPs. Second, this study bridges the gap between exhibition experiential value and CCP experiential value. It validates the proposal that exhibition experiential value can bolster CCP experiential value. The result confirms that exhibitions enhance the sustainability of these tourism destinations by offering creative contents and services. This finding also validates and enriches current studies on creative tourism [11] Third, this study validates the relationship between park experiential value and behavioral intentions; thus, it validates how $\mathrm{CCP}$ experiential value mediates the relationship between exhibition experiential value and visitor behavioral intentions. Fourth, this study also validates how exhibition experiential value mediates the relationship between the antecedents of exhibition experiential value and $\mathrm{CCP}$ experiential value. From the perspective of contribution to management practice, the research results not only enhance the marketing ability of the cultural and creative park and help to realize sustainable development but also enhance its exhibition 
experiential value, as well as its overall operational performance-all based on a thorough understanding of better planning and organization of the exhibitions held in the park.

\section{Theoretical Background and Hypothesis Development}

\subsection{MR Model}

We adopted the Mehrabian and Russell (MR) model, which mainly focuses on the effects of environmental stimuli on humans, as the fundamental framework for this research. It is believed that stimulus has an impact on the individual organisms and that, in turn, this impact has an effect on the behavioral responses of individuals [24]. This model has been widely applied in the field of tourism research [25-28]. For example, in the context of heritage tourism, Su and Hsu [26] confirmed that service fairness can influence visitors' positive emotions and their subsequent word-of-mouth. In the context of mobile social tourism shopping, Hew et al. [28] found that visitors' perception of environmental stimuli (i.e., social presence with the tourism platform) affects their organisms' states (i.e., perceived the platform enjoyment.), which in turn, affects their behavioral intentions.

Following previous scholars' study [25-28], this study adopts the MR model, further explores it, and applies it to tourism research. In this study, the antecedents of a park's exhibition fall under the category of stimuli, whereas both exhibition experiential value perception and CCP experiential value perception fall under the category of individual organisms, and the visitors' behavioral intentions toward the CCP fall under the category of responses. In other words, the antecedents of exhibition experiential value, such as attractiveness, existential authenticity, self-congruence, and exhibition-park image congruence, are presumed to stimulate visitors' perception of exhibition experiential value, which has an impact on their CCP experiential value, which in turn affects their behavioral intentions toward the park. In summary, Figure 1 depicts the conceptual model.

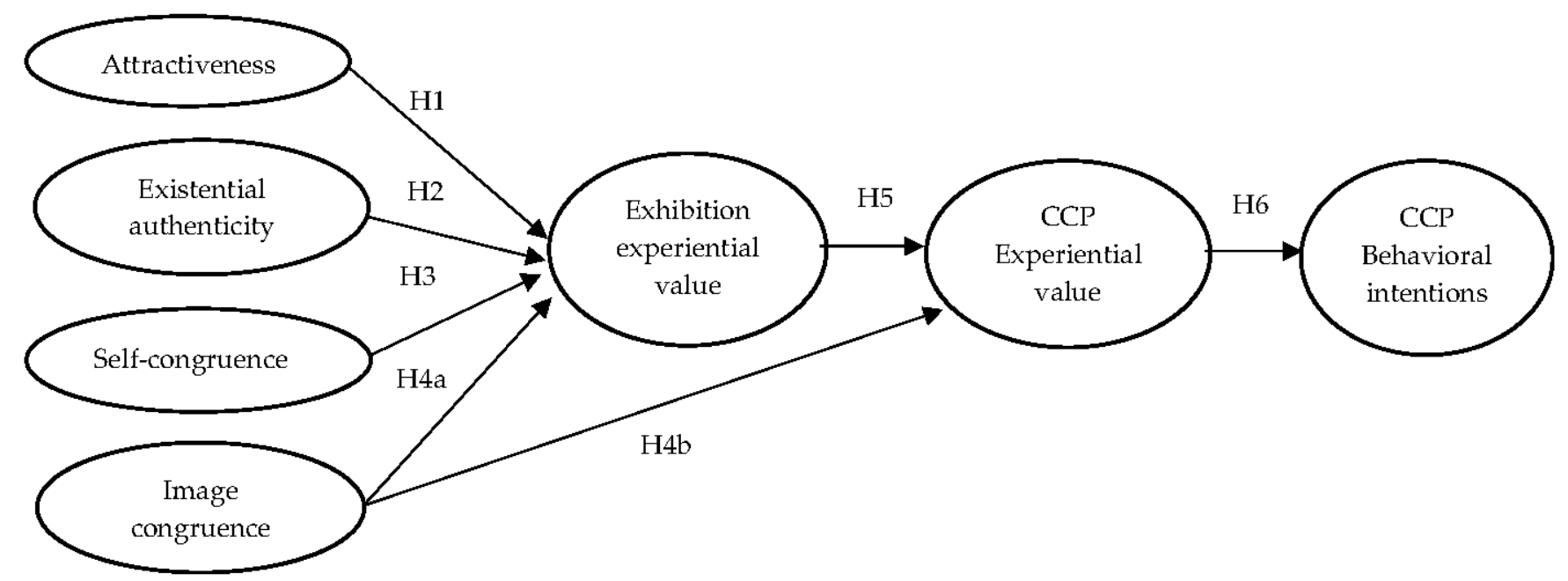

Figure 1. Conceptual model.

\subsection{Experiential Value}

Pine and Gilmore [29] argued that in an experiential economy, the income of organizations is correlated with the experiential value that their products provide. Experiential value refers to the perceived value that consumers derive from direct use or indirect observation of a product or service [30]. Experiential value is a multi-dimensional construct that consists of cognitive, affective, intellectual, and behavioral dimensions associated with the service experience [31]. Holbrook [32] emphasized the experiential value brought by consumers' consumption experience process and divided the experiential value into four quadrants based on the two dimensions of internal/external value and active/reactive value. Based on the quadrantals divided by Holbrook [32], Mathwick et al. [30] proposed 
the four dimensions of experiential value and the experiential value scale (EVS), including consumer return on investment, service excellence, playfulness, and aesthetics, which have been widely applied in tourism research $[7,12,33]$. The experiential value theory has been widely employed in the study of consumer behavior [33].

In the context of tourism, the experiential value is the process by which visitors perceive the benefits they derive from their travel and stay at a particular destination, including the assets or resources that they, together with other visitors and the property owner, invest in creating the experience [34]. This study adopts the experiential value perspective of Mathwick et al. [30], focusing on the impact factors that influence visitors' experiential value of the exhibitions held in a CCP. Furthermore, this study explores whether exhibition experiential value has an impact on visitors' experiential value and behavioral intentions toward CCPs.

\subsection{CCP Experiential Value and Exhibition Experiential Value}

A CCP is a place and space that creates an environment where cultural and creative activities, products, and services are provided to satisfy visitors' needs [6,7,35-37]. To attract and satisfy visitors, CCP managers should pay more attention to understanding visitors' perception and CCP experiential value [7]. The formation of the perception of experiential value is based on the numerous attractions that a CCP has to offer, from architectures and exhibitions to the souvenirs sold in the gift shop. Hung et al. [7] suggested that a park can increase its experiential value by providing a playful environment, superior staff service, upgraded aesthetics, and a quality ambiance.

Some parks attach great importance to enhancing CCP experiential value by organizing various exhibitions as a key development strategy. For example, Taipei Huashan 1914 Creative Park and Taipei Songshan Cultural and Creative Park have attached great importance to exhibitions and frequently host exhibitions with various themes. In 2018, Huashan 1914 Creative Park held 128 exhibitions, while Songshan Cultural and Creative Park held 157 exhibitions, amounting to an average of over 10 multiple-themes per month. Exhibitions at CCPs can increase the value of CCPs and enhance creative tourism and its sustainability by offering innovative products and services [4,11].

Regarding visitors, an exhibition is a highly experience-oriented product [38]. Exhibition experiential value is influenced by many factors. For example, Lee and Min [16] found that the quality of the exhibition itself (e.g., exhibit program, admission experience, site environment) has a direct impact on the exhibition experiential value. However, research on the impact factors of exhibition experiential value remains relatively scarce, which calls for further investigation.

\subsection{Antecedents of Exhibition Experiential Value}

\subsubsection{Attractiveness}

The attractiveness of the destination has a pulling effect on the visitors [6,18,39], which is a key factor to drive people to the particular destination. In this research, attractiveness refers to the destination's ability to provide the benefits that the visitors seek [40], reflected in the visitors' perception of the destination's capability to meet their specific travel needs [39].

As a pull motivation, attractiveness has an effect on visitors' experiential value. Studies in ecotourism parks and malls have all confirmed that attractiveness can enhance visitors' experiential value $[18,41]$. For example, in ecotourism destination research, the attractiveness of an ecotourism destination has a significant positive effect on the visitors' experiential value [18]. Tandon et al. [41] identified that the attractiveness of mall atmospherics has a positive effect on the value of the mall shopping experience. Based on the research findings above, we conclude with the hypothesis:

Hypothesis 1 (H1). Exhibition attractiveness has a positive effect on exhibition experiential value. 


\subsubsection{Existential Authenticity}

In the tourism sector, existential authenticity, related to activities, is the state of being that is conceived by way of the visitor's participation in the touristic activities [42]. Existential authenticity takes place when there is a connection between the visitor and the destination, where the "existence" state is activated in relation to the visitor in action [42]. In this study, existential authenticity refers to an exhibition's ability to allow visitors to enter a special state of being in which they are true to themselves.

Scholars in the field of tourism have paid much attention to existential authenticity [43-45]; this study also adopts the same perspective. Scholars have found that existential authenticity has a positive effect on visitors' experiential value. In heritage tourism, visitors participate in activities associated with heritage-related activities that contribute to existential authenticity, which in turn, influences their perceived value of the experience [46]. Domínguez-Quintero et al. [47] found that the higher the visitor's perception of existential authenticity is, the better the quality of the visitor's experience.

Based on the discussion above, the influence of existential authenticity on the value of visitor experience can be found. We infer that when visitors' existential authenticity is stimulated by the exhibition, it affects the value of visitors' experience of the exhibition. This leads to the following hypothesis.

Hypothesis 2 (H2). Existential authenticity has a positive effect on exhibition experiential value.

\subsubsection{Self-Congruence}

Self-congruence is defined as the degree of match between the product image and the consumer's self-concept $[48,49]$. Self-concept reflects "all of the individual's thoughts and feelings about themselves as an object" [50]. Self-concept is a multidimensional concept that consists of the real self, the ideal self, the social self, and the ideal social self $[48,49]$. Consumers reinforce their self-concept by choosing to purchase products that are self-congruent [48]. In this study, self-congruence refers to the congruence between the exhibition's image and the visitor's self-concept.

At present, few studies have examined the impact of self-congruence on exhibition experiential value; however, past research might be able to provide some cues. For example, Luna-Cortés [20] pointed out that self-congruence promotes customers' experiential value when they use their digital social networks. Self-congruence contributes to the experiential value of shopping [51]. Moreover, studies in the tourism industry have found that selfcongruity has various effects on tourists' experiential value. For example, tourists' selfcongruity has an effect on their perceived value of a destination [52]. Based on the above, this study proposes the following hypothesis:

Hypothesis 3 (H3). Self-congruence has a positive effect on exhibition experiential value.

\subsubsection{Exhibition-Park Image Congruence}

Image congruence is defined as the consumer's personal judgment toward the image consistency and compatibility between products and other objects [22]. For example, the restaurant-guest image congruence refers to whether consumers perceive the chef's image as compatible and consistent with the restaurant [21]. In this study, exhibition-park image congruence refers to the visitor's assessment of the alignment between the exhibition's image and the $\mathrm{CCP}^{\prime}$ s image.

Regarding co-branding theory and the match-up hypothesis, the former believes that the pairing between an event and the brand image of the destination will shift the image perception of the event to that of the destination; the latter predicts an effect of image transfer influenced by the degree of matching between the event and the destination brand [53]. In addition, other studies have found that image congruence has an impact on consumer behaviors. For instance, in a study on the relationship between a racing event and its host city, Hallmann and Breuer [22] found that the congruence between the image of the marathon 
and that of the host city has an impact on visitors' satisfaction and their willingness to revisit the host city. Likewise, consumers' judgment of the degree of suitability of an event held by a particular shopping outlet has an effect on their satisfaction with the event and their shopping enjoyment [23]. Similarly, consumers' perception of the image congruence of a luxury restaurant and a guest chef has an effect on their perception of the restaurant [21].

Regarding CCPs, each park possesses its own characteristics and positioning in creating a specific image. The congruence between the image of a park and that of an exhibition held in the park is vital for the experiential value for both the park and the exhibition. Based on the research findings of previous scholars, we propose the following hypothesis:

Hypothesis 4 (H4). Exhibition-park image congruence has a positive effect on (a) exhibition experiential value and (b) CCP experiential value.

\subsection{The Influence of Exhibition Experiential Value on CCP Experiential Value}

Previous scholars have pointed out that as one of the elements of a park for arousing visitors' emotions, exhibitions can affect the park's ratings, which is a topic that warrants further research [7]. In this paper, when visitors visit a CCP-held exhibition, they develop an assessment based on their observations, contacts, and onsite product and service consumption [30]. Exhibitions can enrich visitors' value perception and enhance the attractiveness and competitiveness of the park. For the CCP managers, an exhibition can serve as one product that brings experiential value to visitors.

At present, the topic of exhibition experiential value as related to CCPs has not been established; however, other studies provide useful references for examining the relationship between the two. For instance, Lee et al. [54] found that visitors' satisfaction with a festival has an effect on their attachment to the host destination, which in turn, affects their loyalty to the destination. Tsaur et al. [55] found that festival attachment positively affects attachment and loyalty to the festival destination. We extend this logic and infer the following hypothesis:

Hypothesis 5 (H5). Exhibition experiential value has a positive effect on CCP experiential value.

\subsection{The Effect of CCP Experiential Value on Behavioral Intentions}

In this study, behavioral intentions mainly refer to visitors' behavior of revisiting a CCP and advocating for the CCP through word of mouth [56]. The services experienced by the consumers can affect their behavioral intentions [57]. The better the service experience consumers perceive, the greater the likelihood that they will have favorable behavioral intentions.

In the tourism industry, stimulating factors inspire the consumers' experiential value perception, which, as an intrinsic psychological evaluation, affects their behavioral intentions. In a water park, visitors' experience quality affects their experiential value perception and their behavioral intentions toward the park [58]. At ecotourism destinations, the experiential value of the destination has a positive effect on visitors' behavioral intentions [18]. Based on the research findings above, we propose the following hypothesis:

Hypothesis 6 (H6). CCP experiential value has a positive impact on visitors' CCP behavioral intentions.

\section{Research Method}

\subsection{Research Context}

In this study, cultural and creative parks are parks located in cities that integrate production and consumption of arts and cultural creative activities [35-37]. These parks are transformed from abandoned industrial cultural sites in a specific and spatially limited area [35-37], such as New York's SOHO, Sheffield's Cultural Industries Quarter. Cultural and creative parks have more cultural and creative production and consumption activities and facilities than other sites [35-37], and they have become important cultural and creative tourist attractions for visitors [6,7]. 
Huashan 1914 Creative Park and Songshan Cultural and Creative Park are two wellknown CCPs in Taipei and the two largest CCPs in Taiwan. They are also successful examples of the development of cultural and creative parks in China. These two parks have seen the transformation from a wine factory and a tobacco factory, respectively. These two parks have many production and consumption activities and facilities of culture and creativity that can meet people's demand for cultural and creative production and consumption. These two parks attract a large number of cultural and creative producers and consumers, and they are important attractions in Taiwan's cultural and creative tourism. Today, they are both regarded as role models for successful conversions from industrial cultural heritages to CCPs. In recent years, many scholars have chosen them as their related study context $[7,9]$. Hence, we chose these two CCPs as the research context in this study.

\subsection{Respondents and Procedure}

From May to June 2019, we conducted a survey at the Huashan 1914 Creative Park and the Songshan Cultural and Creative Park in Taipei. We adopted a purposive sampling method for data collection. A set of screening questions was asked. Considering one of the objectives of this research is to examine visitors' exhibition experiential value influence on CCP experiential value, we confirm the primary purpose of interviewees is to visit the exhibition at CCPs before filling out the questionnaire. The well-trained interviewers provided the respondents with brief information about the purpose, usage, and confidentiality of the study to ensure that the survey was conducted on a voluntary basis. The entire questionnaire took approximately $15 \mathrm{~min}$ to complete. Finally, 500 questionnaires were collected on-site, and after deleting incomplete questionnaires, 428 valid questionnaires were obtained, with a valid response rate of $85.6 \%$. Among them, 210 questionnaires were obtained from Huashan 1914 Creative Park and 218 from Songshan Cultural and Creative Park. These respondents were all visitors from other places to Taipei. See Table 1 for demographic profile of the respondents.

Table 1. Characteristics of the participants $(\mathrm{N}=428)$.

\begin{tabular}{ccc}
\hline Demographic Traits & & $\%$ \\
\hline \multirow{2}{*}{ Gender } & Male & 37.62 \\
& Female & 62.38 \\
\hline \multirow{3}{*}{ Age } & Below20 & 9.11 \\
& $21-30$ & 43.22 \\
& $31-40$ & 30.61 \\
& $41-50$ & 9.58 \\
& 51 or above & 7.48 \\
\hline \multirow{2}{*}{ Education } & High school degree & 10.98 \\
& University & 49.53 \\
& Postgraduate degree or above & 24.07 \\
& Other degree & 15.42 \\
\hline
\end{tabular}

\subsection{Questionnaire Design and Measures}

The survey mainly consists of two parts: In the first part, the respondents were asked to provide their demographic information, such as age, gender, and level of education; this part of the survey also required the respondents to fill out the name of the exhibition attended. In the second part, a 7-point Likert scale ranging from extremely disagree (1) to extremely agree (7) was used; this part of the survey required the respondents to evaluate the degree of attractiveness, self-congruence, exhibition-park congruence, exhibition existential authenticity, exhibition experiential value, CCP experiential value, and visitors' behavioral intentions. For the sake of content validity, the questions were revised based on relevant scales in the existing literature in conjunction with the context of the study [59]. See Table 2 for the measurement items. 
Prior to the survey, a two-stage questionnaire pretest was conducted with regard to the rationality and validity of the questionnaires and measurement scales [7,60]. We sought advice from the managers and researchers of the CCPs with regard to the rationality and comprehensibility of the selected questionnaires and measurement scales based on which necessary adjustments were made. Then, we chose 30 respondents for the pretest to assess the reliability and validity of the measurement items.

\subsection{Data Analysis}

This study adopted the IBM SPSS AMOS 24 to perform data analysis according to the two-step approach of Anderson and Gerbing [61], including confirmatory factor analysis (CFA) and structural equation modeling (SEM). Through the use of CFA, the study was able to examine the relationship between observed variables and latent variables in the measurement model; and goodness of fit index and the hypotheses were tested through SEM.

\section{Results}

\subsection{Measurement Model}

We conducted a CFA to test fit indices, convergent validity, and discriminant validity of the measurement model. First, the overall fit of the measurement model indicates that $\chi^{2}=1841.599$, where $\mathrm{df}=873 . \chi^{2} / \mathrm{df}=2.109$ is less than 3 ; comparative fit index (CFI), normed fit index (NFI), and incremental fit index (IFI) are all greater than the recommended threshold of 0.90; and with RMSEA less than 0.08, the model has a good fit [62].

As for the testing of the convergent validity of the measurement model, the standard factor loadings of the variables distribute between 0.619 and 0.949 and each is greater than 0.6, as shown in Table 2 [63]. Moreover, Table 3 shows that each of the constructs has an average variance extracted (AVE) value greater than 0.5 and construct reliability (CR value) greater than 0.8 [64]; therefore, the measurement model satisfies the test requirements for convergent validity.

Table 2. Confirmatory factor analysis: items and loading $(\mathrm{N}=428)$.

\begin{tabular}{|c|c|c|c|}
\hline Construct & Adopted from & Items & $\begin{array}{c}\text { Standard Factor } \\
\text { Loading }\end{array}$ \\
\hline \multirow{3}{*}{ Attractive (AT) } & \multirow{3}{*}{$\begin{array}{c}\text { Rahman [65], } \\
\text { Chen and Chou [5] }\end{array}$} & AT1: The exhibition is fashionable. & 0.923 \\
\hline & & AT2: The exhibition is hot. & 0.944 \\
\hline & & AT3: The exhibition is stylish. & 0.715 \\
\hline \multirow{4}{*}{$\begin{array}{l}\text { Self-congruence } \\
\text { (SELF) }\end{array}$} & \multirow{4}{*}{$\begin{array}{l}\text { Luna-Cortés et al. } \\
{[66]}\end{array}$} & SELF1: I completely identify myself with the exhibition experience. & 0.911 \\
\hline & & SELF 2: I identify myself with the people who visit the exhibition. & 0.945 \\
\hline & & $\begin{array}{c}\text { SELF 3: This kind of exhibition experience is consistent with how I like to } \\
\text { see myself. }\end{array}$ & 0.858 \\
\hline & & SELF 4: The exhibition experience corresponds to how I like others to see me. & 0.646 \\
\hline \multirow{3}{*}{$\begin{array}{l}\text { Image congruence } \\
\text { (IC) }\end{array}$} & \multirow{3}{*}{ Chen et al. [20] } & IC1: The image of CCP and exhibition is consistent with one another. & 0.872 \\
\hline & & IC2: The image of CCP and exhibition is complementary of one another. & 0.949 \\
\hline & & IC3: The image of CCP and exhibition fits one another. & 0.940 \\
\hline \multirow{3}{*}{$\begin{array}{c}\text { Existential } \\
\text { authenticity (EAU) }\end{array}$} & \multirow{3}{*}{ Jiang et al. [67] } & EAU1: I am able to discover more about myself at the exhibition. & 0.860 \\
\hline & & EAU2: I am in touch with my feelings and emotions at the exhibition. & 0.726 \\
\hline & & EAU3: Visitors at the exhibition interact with each other in a genuine way. & 0.732 \\
\hline $\begin{array}{c}\text { Exhibition } \\
\text { experiential value } \\
(E E V)\end{array}$ & Mathwick et al. [30] & & \\
\hline \multirow{4}{*}{$\begin{array}{l}\text { Consumer return on } \\
\text { investment (Ecr) }\end{array}$} & \multirow{4}{*}{$\begin{array}{c}\text { Tsai and Wang [68], } \\
\text { Lee et al. [69] }\end{array}$} & Ecr1: Visiting the exhibition has good economic value. & 0.801 \\
\hline & & Ecr 2: I am willing to wait in line to visit the exhibition. & 0.778 \\
\hline & & Ecr 3: I am happy with the price of visiting the exhibition. & 0.833 \\
\hline & & Ecr 4: The total expenditure of visiting the exhibition is acceptable. & 0.619 \\
\hline \multirow{3}{*}{$\begin{array}{l}\text { Service excellence } \\
\text { (Eser) }\end{array}$} & \multirow{3}{*}{$\begin{array}{l}\text { Lee and Min [15], } \\
\text { Wong et al. [70] }\end{array}$} & Eser 1: I have an excellent experience at the exhibition. & 0.876 \\
\hline & & Eser 2: I experience outstanding service at the exhibition. & 0.917 \\
\hline & & Eser 3: When I think of the exhibition, I think of excellence. & 0.928 \\
\hline
\end{tabular}


Table 2. Cont.

\begin{tabular}{|c|c|c|c|}
\hline Construct & Adopted from & Items & $\begin{array}{l}\text { Standard Factor } \\
\text { Loading }\end{array}$ \\
\hline \multirow{3}{*}{ Aesthetics (Eae) } & \multirow{3}{*}{$\begin{array}{c}\text { Ahn et al. [11], } \\
\text { Tsai and Wang [68] }\end{array}$} & Eae 1: The environment of the exhibition is aesthetically appealing. & 0.874 \\
\hline & & Eae 2: I like the way the exhibition looks. & 0.928 \\
\hline & & Eae 3: The style of the exhibition is very impressive. & 0.892 \\
\hline \multirow{4}{*}{ Playfulness (Eplay) } & \multirow{4}{*}{ Tsai and Wang [68] } & Eplay 1: Visiting the exhibition let me forget worries. & 0.831 \\
\hline & & Eplay 2: Visiting the exhibition makes me feel like I am in another world. & 0.907 \\
\hline & & Eplay 3: I enjoy the style the exhibition displayed. & 0.932 \\
\hline & & Eplay 4: I perceive the pure enjoyment of visiting the exhibition. & 0.864 \\
\hline $\begin{array}{l}\text { CCP Experiential } \\
\text { value (CCPEV) }\end{array}$ & Mathwick et al. [30] & & \\
\hline \multirow{4}{*}{$\begin{array}{l}\text { Consumer return on } \\
\text { investment (Pcr) }\end{array}$} & \multirow{4}{*}{$\begin{array}{l}\text { Tsai and Wang [68], } \\
\text { Lee et al. [69] }\end{array}$} & Pcr 1: Visiting (the CCP name) has good economic value. & 0.822 \\
\hline & & Pcr 2: I am willing to wait in line to visit (the CCP name). & 0.886 \\
\hline & & Pcr 3: I am happy with the price of visiting (the CCP name) & 0.885 \\
\hline & & Pcr 4: The total expenditure of visiting (the CCP name) is acceptable & 0.768 \\
\hline \multirow{3}{*}{$\begin{array}{l}\text { Service excellence } \\
\text { (Pser) }\end{array}$} & \multirow{3}{*}{$\begin{array}{l}\text { Lee and Min [15], } \\
\text { Wong et al. [70] }\end{array}$} & Pser 1: I have an excellent experience at (the CCP name). & 0.918 \\
\hline & & Pser 2: I experience outstanding service at (the CCP name). & 0.942 \\
\hline & & Pser 3: When I think of (the CCP name), I think of excellence. & 0.940 \\
\hline \multirow{3}{*}{ Aesthetics (Pae) } & \multirow{3}{*}{$\begin{array}{l}\text { Ahn et al. [11], } \\
\text { Tsai and Wang [68] }\end{array}$} & Pae 1: The environment of (the CCP name) is aesthetically appealing. & 0.846 \\
\hline & & Pae 2: I like the way (the CCP name) looks. & 0.918 \\
\hline & & Pae 3: The style of (the CCP name) is very impressive. & 0.902 \\
\hline \multirow{4}{*}{ Playfulness (Pplay) } & \multirow{4}{*}{ Tsai and Wang [68] } & Pplay 1: Visiting (the CCP name) lets me forget worries. & 0.833 \\
\hline & & Pplay 2: Visiting (the CCP name) makes me feel like I am in another world. & 0.924 \\
\hline & & Pplay 3: I enjoy the style (the CCP name) displayed. & 0.911 \\
\hline & & Pplay 4: I perceive the pure enjoyment of visiting (the CCP name). & 0.767 \\
\hline \multirow{3}{*}{$\begin{array}{l}\text { Behavioral intentions } \\
\text { (BI) }\end{array}$} & \multirow{3}{*}{$\begin{array}{c}\text { Jang and Namkung } \\
{[71]}\end{array}$} & BI1: I would like to come back to (the CCP name) in the future. & 0.923 \\
\hline & & BI2: I would say positive things about (the CCP name) to others & 0.934 \\
\hline & & BI3: I will recommend (the CCP name) to my friends or others. & 0.829 \\
\hline
\end{tabular}

Table 3. Results of convergent validity and discriminant validity.

\begin{tabular}{|c|c|c|c|c|c|c|c|c|c|c|c|c|c|c|c|c|c|}
\hline & $\begin{array}{l}\text { Mean } \\
\text { (SD) }\end{array}$ & $\mathrm{CrA}$ & CR & AVE & EAU & IC & $\mathrm{AT}$ & BI & SELF & Pcr & Pser & Pae & Pplay & Eplay & Eser & Eae & Ecr \\
\hline EAU & $\begin{array}{l}5.459 \\
(0.933)\end{array}$ & 0.811 & 0.818 & 0.601 & 0.775 & & & & & & & & & & & & \\
\hline IC & $\begin{array}{l}5.123 \\
(1.098)\end{array}$ & 0.943 & 0.944 & 0.848 & 0.302 & 0.921 & & & & & & & & & & & \\
\hline AT & $\begin{array}{c}4.967 \\
(1.008)\end{array}$ & 0.892 & 0.899 & 0.751 & 0.405 & 0.324 & 0.867 & & & & & & & & & & \\
\hline BI & $\begin{array}{l}5.306 \\
(1.141)\end{array}$ & 0.921 & 0.924 & 0.803 & 0.387 & 0.446 & 0.356 & 0.896 & & & & & & & & & \\
\hline SELF & $\begin{array}{l}4.692 \\
(1.102)\end{array}$ & 0.903 & 0.910 & 0.720 & 0.415 & 0.453 & 0.564 & 0.504 & 0.849 & & & & & & & & \\
\hline Pcr & $\begin{array}{l}5.063 \\
(1.004)\end{array}$ & 0.902 & 0.906 & 0.708 & 0.521 & 0.515 & 0.426 & 0.658 & 0.514 & 0.841 & & & & & & & \\
\hline Pser & $\begin{array}{l}4.991 \\
(0.887)\end{array}$ & 0.953 & 0.953 & 0.871 & 0.513 & 0.507 & 0.419 & 0.648 & 0.506 & 0.800 & 0.933 & & & & & & \\
\hline Pae & $\begin{array}{l}5.241 \\
(0.966)\end{array}$ & 0.918 & 0.919 & 0.791 & 0.521 & 0.514 & 0.425 & 0.658 & 0.513 & 0.812 & 0.799 & 0.889 & & & & & \\
\hline Pplay & $\begin{array}{l}5.179 \\
(0.991)\end{array}$ & 0.915 & 0.919 & 0.742 & 0.538 & 0.530 & 0.439 & 0.679 & 0.529 & 0.838 & 0.825 & 0.837 & 0.861 & & & & \\
\hline Eplay & $\begin{array}{l}5.244 \\
(1.068)\end{array}$ & 0.933 & 0.935 & 0.783 & 0.589 & 0.449 & 0.551 & 0.536 & 0.591 & 0.627 & 0.617 & 0.626 & 0.646 & 0.885 & & & \\
\hline Eser & $\begin{array}{l}5.233 \\
(0.955)\end{array}$ & 0.932 & 0.933 & 0.823 & 0.497 & 0.379 & 0.465 & 0.453 & 0.499 & 0.529 & 0.521 & 0.529 & 0.546 & 0.687 & 0.907 & & \\
\hline Eae & $\begin{array}{l}5.401 \\
(1.075)\end{array}$ & 0.925 & 0.926 & 0.807 & 0.578 & 0.441 & 0.541 & 0.526 & 0.580 & 0.615 & 0.606 & 0.615 & 0.634 & 0.798 & 0.674 & 0.898 & \\
\hline Ecr & $\begin{array}{l}5.099 \\
(1.019)\end{array}$ & 0.839 & 0.846 & 0.581 & 0.589 & 0.449 & 0.551 & 0.536 & 0.592 & 0.627 & 0.618 & 0.627 & 0.647 & 0.813 & 0.687 & 0.798 & 0.762 \\
\hline
\end{tabular}


With regard to the testing of the measurement model's discriminant validity, Fornell and Lacker [64] suggested that the square root of the AVE of each construct must be greater than the correlation coefficients between the construct and other constructs. As shown in Table 3, the measurement model satisfies the test requirements for discriminant validity.

\subsection{Structural Model and Hypotheses Testing}

This study uses maximum-likelihood estimation to analyze the structural model to test the goodness of fit of the model and the validity of each hypothesis. The fit indices indicate that the model has a good fit $\left(\chi^{2}=1860.944 ; \mathrm{df}=881 ; \chi 2 / \mathrm{df}=2.112 ; \mathrm{CFI}=0.947\right.$; $\mathrm{NFI}=0.904 ; \mathrm{IFI}=0.947$; RMSEA $=0.051$ ).

Table 4 shows the results of this research. All of the hypotheses are supported. All four antecedents of the exhibition experiential value have a positive impact on the exhibition experiential value. Furthermore, both exhibition-park image congruence and exhibition experiential value have a positive impact on CCP experiential value. Finally, CCP experiential value has a positive impact on visitors' CCP behavioral intentions.

Table 4. Hypotheses tests (H1-H6).

\begin{tabular}{cccc}
\hline Path & Standard Estimate & T & Results \\
\hline H1: $\mathrm{AT} \rightarrow \mathrm{EEV}$ & $0.230^{* * *}$ & 4.853 & Support \\
$\mathrm{H} 2: \mathrm{EAU} \rightarrow \mathrm{EEV}$ & $0.400^{* * *}$ & 7.652 & Support \\
H3: $\mathrm{SELF} \rightarrow \mathrm{EEV}$ & $0.289^{* * *}$ & 5.747 & Support \\
H4a: $\mathrm{IC} \rightarrow \mathrm{EEV}$ & $0.172^{* * *}$ & 4.226 & Support \\
H4b: $\mathrm{IC} \rightarrow \mathrm{CCPEV}$ & $0.244^{* * *}$ & 5.956 & Support \\
H5: $\mathrm{EEV} \rightarrow \mathrm{CCPEV}$ & $0.663^{* * *}$ & 10.071 & Support \\
H6: $\mathrm{CCPEV} \rightarrow \mathrm{BI}$ & $0.736^{* * *}$ & 15.166 & Support \\
\hline
\end{tabular}
Note: ${ }^{* * *} p<0.001$.

The purpose of this study is to explore the antecedents of exhibition experiential value and the impact of exhibition value on CCPs. However, this study seeks to further explore an important topic - the potential mediation role of exhibition experiential value between the antecedents and CCP experiential value, as well as the mediating effect of the CCP experiential value on the relationship between exhibition experiential value and visitors' behavioral intentions. As the method for testing these mediating effects, we adopted the bootstrap method to carry out the mediation tests, following the suggestions of Preacher and Hayes [72].

The sample size was set at 2000 and bias-corrected confidence estimates were adopted to obtain a 95\% confidence interval. As shown in Table 5, exhibition experiential value had a full mediation effect on the relationship between exhibition attractiveness and CCP experiential value and on the relationship between self-congruence and CCP experiential value. In addition, CCP experiential value had a full mediating effect on the relationship between exhibition experiential value and visitors' behavioral intentions. Exhibition experiential value had a partial mediating effect on the relationship between exhibition existential authenticity and CCP experiential value and the relationship between exhibition-park image congruence and CCP experiential value.

Table 5. Test for mediation with bootstrap procedures.

\begin{tabular}{|c|c|c|c|c|c|c|}
\hline \multirow{3}{*}{ Path } & \multicolumn{6}{|c|}{ Bias-Corrected $95 \% \mathrm{CI}$} \\
\hline & \multicolumn{2}{|c|}{ Total Effects } & \multicolumn{2}{|c|}{ Direct Effects } & \multicolumn{2}{|c|}{ Indirect Effects } \\
\hline & Lower & Upper & Lower & Upper & Lower & Upper \\
\hline $\mathrm{AT} \rightarrow \mathrm{CCPEV}$ & 0.020 & 0.243 & -0.160 & 0.094 & 0.075 & 0.256 \\
\hline $\mathrm{EAU} \rightarrow \mathrm{CCPEV}$ & 0.243 & 0.464 & 0.011 & 0.260 & 0.120 & 0.325 \\
\hline $\mathrm{SELF} \rightarrow \mathrm{CCPEV}$ & 0.105 & 0.278 & -0.030 & 0.168 & 0.068 & 0.193 \\
\hline $\mathrm{IC} \rightarrow \mathrm{CCPEV}$ & 0.208 & 0.367 & 0.126 & 0.286 & 0.033 & 0.142 \\
\hline $\mathrm{EEV} \rightarrow \mathrm{BI}$ & 0.467 & 1.047 & -0.128 & 0.423 & 0.378 & 0.919 \\
\hline
\end{tabular}




\section{Discussions}

In the era of experiential economy, visitors' experiential value is of the utmost importance for the management and sustainable development of CCPs [6]. This study mainly examines the antecedents and consequences of exhibition experiential value and analyzes the exhibition-park relationship in the context of CCPs. The findings confirm four antecedents of exhibition experiential value. Furthermore, the findings also confirm the relationships among the four antecedents, exhibition experiential value, CCP experiential value, and behavioral intentions. These findings provide useful insights for scholars in CCPs to support the sustainable development of CCPs.

First, this study proposes and validates four factors that influence the experiential value of the exhibition in CCPs-attractiveness, existential authenticity, self-congruence, and exhibition-park image congruence. Among these four factors, existential authenticity has the strongest influence on the exhibition experiential value, followed by selfcongruence, attractiveness, and exhibition-park image congruence. Specifically, existential authenticity is an important force driving visitors to generate touristic behaviors $[73,74]$ and has a positive impact on the visitor experience [60]. As found in this study, if visitors are inspired by the exhibition when they visit the exhibition, they will better perceive the experiential value of the exhibition. Regarding the impact of self-congruence, as Elliott and Wattanasuwan [75] pointed out, reinforcing self-concept and gaining self-identity are the key factors affecting consumer experience in postmodern consumption. Therefore, for the visitors of the exhibition, they also pay attention to whether the exhibition matches their self-image and whether it affects the presentation of their self-image. As concluded in this study, the higher the congruence between visitors' self-concept and the image of the exhibition held in the park, the higher the value of the exhibition experience visitors receive. Although, compared with the first two variables, attractiveness has less of an impact on the exhibition experiential value, attractiveness still deserves attention, as a pulling motivation affects visitors' experience [39,76]. If the exhibition held at CCP is attractive to visitors, it will help improve visitors' experiential value perception of the exhibitions. At last, when the CCP holds an exhibition that matches the image of the park, it helps visitors to get the exhibition experiential value. The higher this consistency, the higher the value of the visitor's experience. By studying the effects of attractiveness, existential authenticity, self-congruence, and exhibition-park image congruence on exhibition experiential value, research on the influencing factors of exhibition experiential value is significantly improved and enriched, which further improves our understanding of the critical success factors in organizing exhibitions, enriching the content of creative tourism in CCPs. Compared with previous research on exhibitions, these findings not only enrich the research topics of the exhibition [14-16,77] but also lay the foundation for the study of the antecedents and consequences of the value of the exhibition experience [16].

Second, this study confirms that visitors' experiential value of exhibitions has a positive impact on their CCP experiential value, which in turn, has a significant effect on behavioral intentions. This means that the higher the experiential value visitors get from the exhibition held in the CCP, the higher the experiential value of visitors to the CCP, and that then affects their behavioral intentions toward the CCP. The result is related to the topic of the effect of visitors' evaluation of the events on their behavior to host destinations. Past studies have focused on how visitors' event satisfaction or attachment affects the hosting destination attachment or loyalty $[54,78,79]$. For example, Halpenny et al. [79] confirmed that visitors' attachment to Melissa's Road Race held in Banff National Park affected their attachment to the national park. Lee et al. [54] found that visitors' satisfaction with the festival affected their attachment to the host destination. The result of this study extends prior research by exploring the influence of the experiential value of exhibitions held in the destinations on the destination experiential value. In other words, the result enriches the research on the influence of destination activities on visitors' destination behavior $[54,78,79]$. 
Third, this study proposes and confirms that the visitors' CCP experiential value has a positive impact on their behavioral intentions; that is, it increases visitors' willingness to revisit and to promote CCPs, extending research on the positive effect of experiential value on visitors' behavioral intentions to the CCP context. Furthermore, this study finds that CCP experiential value has a full mediating effect on exhibition experiential value and behavioral intentions toward the CCP. Since visitors' motivation to visit CCPs is complex [60], exhibition experiential value alone may not be sufficient to attract future visitors to such parks. Therefore, exhibition experiential value must act upon CCP experiential value to indirectly influence behavioral intentions towards these parks. This particular finding echoes the findings of the previous literature showing that destination activities contribute to promoting positive experiences in venues, boosting visitors' behavioral intentions [80]. These findings provide references for further research on the relationship between exhibition experiential value, CCP experiential value, and subsequent behaviors.

Fourth, this study validates how exhibition experiential value mediates the relationship between the antecedents of exhibition experiential value and CCP experiential value. The findings show that the influence of exhibition attractiveness and self-congruence on CCP experiential value needs to be realized through the mediating role of exhibition experiential value; existential authenticity and exhibition-park image congruence can directly influence CCP experiential value. These findings deepen the hypothesized conclusions of this research. Compared with previous studies [66], these findings not only examine the factors that directly affect exhibition experiential value, but also provide theoretical insights for further understanding the relationship among the exhibition experiential value, its antecedents, and CCP experiential value.

\section{Conclusions}

CCPs have developed rapidly in recent years as a way for cities to preserve their industrial cultural heritage to achieve sustainable development. In order to achieve better development of CCPs, operators have adopted a variety of approaches. Among them, exhibitions have become one of the most important ways for CCPs to create value and attract visitors. Operators can maintain CCPs competitiveness by improving the experiential value of exhibitions [81]. Under such background, this study explores and confirms the four antecedent variables of the visitors' experiential value of the exhibition (i.e., attractiveness, existential authenticity, self-congruence, and exhibition-park image congruence), and exhibition experiential value has a positive effect on CCP experiential value, which in turn, affects visitors' behavioral intentions to the CCP. Furthermore, this study validates the mediating effect of exhibition experiential value between its four antecedents and the CCP experiential value and the mediating effect of CCP experiential value between the exhibition experiential value and behavioral intentions to the CCP. These findings have important implications for CCP managers.

For CCP managers, they should recognize the function and significance of the exhibitions held in their CCP and pay attention to increase exhibition experiential value. CCP may consider offering exhibitions as basic products and services that they provide to visitors. By staging exhibitions with experiential value on a regular basis, CCP managers can enhance CCP experiential value. In terms of exhibition planning and organization, this study provides CCP managers with general directions and constructive guidance in which the image congruence between the exhibition and the CCP is a fundamental requirement. Visitors will buy in only when the image of the exhibition is consistent with that of the park or when the image perception of the exhibition is reinforced. To ensure exhibition-park image congruence, the likes and preferences of the target visitors must be taken into account, in terms of theme and content selection, to ensure the attractiveness of exhibitions. Regarding the onsite layout and content presentation of exhibitions, park managers should pay attention to how aesthetics are embodied, focus on the styles and characteristics of exhibitions, and accurately communicate the ideas or themes that an exhibition intends to convey to win over the audience with respect to the self-congruence of the exhibition. 
In addition, for both the onsite ambiance and the specific presentation format, efforts must be made to impress visitors with an overall sensory experience. Visitors should be guided to immerse themselves in the context of the exhibition, to excite their emotions and to stimulate their existential authenticity. The image, theme, onsite layout, and content presentation of exhibitions are all relevant to the visitors' exhibitions experiential value.

\section{Limitations and Future Research}

Despite the theoretical and management contributions that this study makes, it also has certain limitations that can be explored in future research. The first limitation lies in the selection of the two CCPs in Taipei as the study subject, the fact that they share certain similarities and are representative of CCPs in Taiwan notwithstanding. Scholars are advised to consider selecting different cities and different types of CCPs to conduct research whose findings have better generalizability. Second, although this study explores how exhibition experiential value impacts CCP experiential value, the impact may vary according to the degree of visitor involvement in exhibitions. Since our research does not address the extent of visitor involvement, future research can explore the impact of the degree of visitor involvement on CCP experiential value. Third, other factors, such as whether the uniqueness of and identification with an exhibition have an effect on exhibition experiential value, can be explored in the future. These factors may help park managers to enhance the exhibition experiential value in the parks.

Author Contributions: H.D. and K.-P.H. conceived the research and collected the data. H.D. wrote the manuscript. K.-P.H., N.P. and A.C. revised and reviewed the manuscript. All authors have read and agreed to the published version of the manuscript.

Funding: This research received no external funding.

Data Availability Statement: The data presented in this study are available on request from the corresponding author.

Conflicts of Interest: The authors declare no conflict of interest.

\section{References}

1. Merino-Aranda, A.; Castillejo-González, I.L.; Velo-Gala, A.; de Paula Montes-Tubío, F.; Mesas-Carrascosa, F.J.; Triviño-Tarradas, P. Strengthening Efforts to Protect and Safeguard the Industrial Cultural Heritage in Montilla-Moriles (PDO). Characterisation of Historic Wineries. Sustainability 2021, 13, 5791. [CrossRef]

2. Li, Y. Old Factories Bringing New Vitality to Beijing. Available online: http://www.chinadaily.com.cn/cndy/2018-07/24 / content_36632072.htm (accessed on 12 March 2021).

3. Murphy, C.; Boyle, E. Testing a conceptual model of cultural tourism development in the post-industrial city: A case study of Glasgow. Tour. Hosp. Res 2006, 6, 111-128. [CrossRef]

4. Richards, G. Creativity and tourism: The state of the art. Ann. Tour. Res. 2011, 38, 1225-1253. [CrossRef]

5. Richards, G.; Raymond, C. Creative tourism. ATLAS News 2000, 23, 16-20.

6. Chen, C.F.; Chou, S.H. Antecedents and consequences of perceived coolness for generation $\mathrm{Y}$ in the context of creative tourism-A case study of the pier 2 art center in Taiwan. Tour. Manag. 2019, 72, 121-129. [CrossRef]

7. Hung, K.P.; Peng, N.; Chen, A. Incorporating on-site activity involvement and sense of belonging into the Mehrabian-Russell model-the experiential value of cultural tourism destinations. Tour. Manag. Perspect. 2019, 30, 43-52. [CrossRef]

8. Zhang, S.N.; Li, Y.Q.; Liu, C.H.; Ruan, W.Q. How does authenticity enhance flow experience through perceived value and involvement: The moderating roles of innovation and cultural identity. J. Travel Tour. Mark. 2019, 36, 711-729. [CrossRef]

9. Chen, A.; Peng, N.; Hung, K.P. Examining tourists' loyalty toward cultural quarters. Ann. Tour. Res. 2015, 51, 59-63. [CrossRef]

10. Liu, C.H. Local and international perspectives of the influence of creative experiences of Chinese traditional culture on revisit intentions. Curr. Issues Tour. 2020, 23, 17-35. [CrossRef]

11. Richards, G.; Wilson, J. Developing creativity in tourist experiences: A solution to the serial reproduction of culture? Tour. Manag. 2006, 27, 1209-1223. [CrossRef]

12. Ahn, Y.J.; Hyun, S.S.; Kim, I. Vivid-memory formation through experiential value in the context of the international industrial exhibition. J. Travel Tour. Mark. 2016, 34, 291-311. [CrossRef]

13. Camarero, C.; Garrido, M.J.; Vicente, E. Components of art exhibition brand equity for internal and external visitors. Tour. Manag. 2010, 31, 495-504. [CrossRef]

14. Fu, X.; Yi, X.; Okumus, F.; Jin, W. Linking the internal mechanism of exhibition attachment to exhibition satisfaction: A comparison of first-time and repeat attendees. Tour. Manag. 2019, 72, 92-104. [CrossRef] 
15. Jin, X.; Weber, K. Developing and testing a model of exhibition brand preference: The exhibitors' perspective. Tour. Manag. 2013, 38, 94-104. [CrossRef]

16. Lee, J.S.; Min, C.K. Examining the quality antecedents and moderating effects of experiential value in a mega-event. J. Travel Tour. Mark. 2016, 33, 326-347. [CrossRef]

17. Walls, A.R.; Okumus, F.; Wang, Y.R.; Kwun, D.J.W. An epistemological view of consumer experiences. Int. J. Hosp. Manag. 2011, 30, 10-21. [CrossRef]

18. Chien, M.C. An empirical study on the effect of attractiveness of ecotourism destination on experiential value and revisit intention. Appl. Ecol. Environ. Res. 2016, 15, 43-53. [CrossRef]

19. Lin, I.Y.; Mattila, A.S. A conceptual model of co-creating an authentic luxury spa experience. Int. J. Spa Wellness 2018, 1, 39-54. [CrossRef]

20. Luna-Cortés, G. The influence of symbolic consumption on experience value and the use of virtual social networks. Span. J. Mark. ESIC 2017, 21, 39-51. [CrossRef]

21. Chen, A.; Peng, N.; Hung, K.P. Examining guest chefs' influences on luxury restaurants' images. Int. J. Hosp. Manag. 2016, 53, 129-132. [CrossRef]

22. Hallmann, K.; Breuer, C. Image fit between sport events and their hosting destinations from an active sport tourist perspective and its impact on future behaviour. J. Sport Tour. 2010, 15, 215-237. [CrossRef]

23. Leischnig, A.; Schwertfeger, M.; Geigenmueller, A. Do shopping events promote retail brands? Int. J. Retail Distrib. Manag. 2011, 39, 619-634. [CrossRef]

24. Mehrabian, A.; Russell, J.A. An Approach to Environmental Psychology; MIT Press: Cambridge, MA, USA, 1974.

25. Ahn, J.A.; Seo, S. Consumer responses to interactive restaurant self-service technology (IRSST): The role of gadget-loving propensity. Int. J. Hosp. Manag. 2018, 74, 109-121. [CrossRef]

26. Su, L.; Hsu, M.K. Service fairness, consumption emotions, satisfaction, and behavioral intentions: The experience of Chinese heritage tourists. J. Travel Tour. Mark. 2013, 30, 786-805. [CrossRef]

27. Namkung, Y.; Jang, S.C. Effects of perceived service fairness on emotions, and behavioral intentions in restaurants. Eur. J. Mark. 2010, 44, 1233-1259. [CrossRef]

28. Hew, J.J.; Leong, L.Y.; Tan, W.H.; Lee, V.H.; Ooi, K.B. Mobile social tourism shopping: A dual-stage analysis of a multi-mediation model. Tour. Manag. 2018, 66, 121-139. [CrossRef]

29. Pine, B.J.; Gilmore, J.H. The Experience Economy: Work Is Theater E Every Business a Stage; Harvard Business Press: Boston, MA, USA, 1999.

30. Mathwick, C.; Malhotra, N.; Rigdon, E. Experiential value: Conceptualization, measurement and application in the catalog and internet shopping environment. J. Retail. 2001, 77, 39-56. [CrossRef]

31. Schmitt, B.H. Experiential Marketing: How to Get Customers to Sense, Feel, Think, Act, and Relate to Your Company and Brands; Free Press: New York, NY, USA, 1999.

32. Holbrook, M.B. The nature of consumer value. In Service Quality: New Directions in Theory and Practice; Rust, R.T., Oliver, R.L., Eds.; Sage Publications: Thousand Oaks, CA, USA, 1994; pp. 21-71.

33. Keng, C.J.; Ting, H.Y. The acceptance of blogs: Using a customer experiential value perspective. Internet Res. 2009, 19, 479-495. [CrossRef]

34. Prebensen, N.K.; Vittersø, J.; Dahl, T.I. Value co-creation significance of tourist resources. Ann. Tour. Res. 2013, 42, $240-261$. [CrossRef]

35. Wansborough, M.; Mageean, A. The Role of Urban Design in Cultural Regeneration. J. Urban Des. 2000, 5, 181-197. [CrossRef]

36. Moss, L. Sheffield's Cultural Industries Quarter 20 Years on: What can be Learned from a Pioneering Example. Int. J. Cult. Policy 2002, 8, 211-219. [CrossRef]

37. Montgomery, J. Cultural Quarters as Mechanisms for Urban Regeneration. Part 1: Conceptualising Cultural Quarters. Planning, Pract. Res. 2003, 18, 293-306. [CrossRef]

38. Gottlieb, U.R.; Brown, M.R.; Drennan, J. The influence of service quality and trade show effectiveness on post-show purchase intention. Eur. J. Mark. 2011, 45, 1642-1659. [CrossRef]

39. $\mathrm{Hu}, \mathrm{Y}$; Ritchie, J.R.B. Measuring destination attractiveness: A contextual approach. J. Travel Res. 1993, 32, 25-34. [CrossRef]

40. Mayo, E.J.; Jarvis, L. The Psychology of Leisure Travel; CBI Publishing Co: Boston, MA, USA, 1981.

41. Tandon, A.; Gupta, A.; Tripathi, V. Managing shopping experience through mall attractiveness dimensions: An experience of Indian metro cities. Asia Pac. J. Mark. Logist. 2016, 28, 634-649. [CrossRef]

42. Wang, N. Rethinking authenticity in tourism experience. Ann. Tour. Res. 1999, 26, 349-370. [CrossRef]

43. Rickly-Boyd, J.M. Existential authenticity: Place matters. Tour. Geogr. 2013, 15, 680-686. [CrossRef]

44. Novello, S.; Fernandez, P.M. The Influence of Event Authenticity and Quality Attributes on Behavioral Intentions. J. Hosp. Tour. Res. 2016, 40, 685-714. [CrossRef]

45. Yu, J.; Li, H.; Xiao, H. Are authentic tourists happier? Examining structural relationships amongst perceived cultural distance, existential authenticity, and wellbeing. Int. J. Tour. Res. 2020, 22, 144-154. [CrossRef]

46. Lee, S.; Phau, I.; Hughes, M.; Li, Y.F.; Quintal, V. Heritage tourism in Singapore Chinatown: A perceived value approach to authenticity and satisfaction. J. Travel Tour. Mark. 2015, 33, 981-998. [CrossRef] 
47. Domínguez-Quintero, A.M.; González-Rodríguez, M.R.; Paddison, B. The mediating role of experience quality on authenticity and satisfaction in the context of cultural-heritage tourism. Curr. Issues Tour. 2020, 23, 248-260. [CrossRef]

48. Sirgy, M.J. Self-Concept in Consumer Behavior: A Critical Review. J. Consum. Res. 1982, 9, 287-300. [CrossRef]

49. Todd, S. Self-concept: A tourism application. J. Consum. Behav. 2001, 1, 184-196. [CrossRef]

50. Rosenberg, M. Conceiving the Self; Basic Books: New York, NY, USA, 1979; p. 7.

51. Paliwoda, S.; Woodruffe-Burton, H.; Wakenshaw, S. Revisiting experiential values of shopping: Consumers' self and identity. Mark. Intell. Planning. 2011, 29, 69-85. [CrossRef]

52. Frías-Jamilena, D.M.; Castañeda-García, J.A.; Del Barrio-García, S. Self-congruity and motivations as antecedents of destination perceived value: The moderating effect of previous experience. Int. J. Tour. Res. 2019, 21, 23-26. [CrossRef]

53. Xing, X.; Chalip, L. Effects of hosting a sport event on destination brand: A test of co-branding and match-up models. Sport Manag. Rev. 2006, 9, 49-78. [CrossRef]

54. Lee, J.; Kyle, G.; Scott, D. The mediating effect of place attachment on the relationship between festival satisfaction and loyalty to the festival hosting destination. J. Travel Res. 2012, 51, 754-767. [CrossRef]

55. Tsaur, S.H.; Wang, Y.C.; Liu, C.R.; Huang, W.S. Festival attachment: Antecedents and effects on place attachment and place loyalty. Int. J. Event Festiv. Manag. 2019, 10, 17-33. [CrossRef]

56. Oliver, R.L. Whence consumer loyalty? J. Mark. 1999, 63, 33-44. [CrossRef]

57. Zeithaml, V.A.; Berry, L.L.; Parasuraman, A. The behavioral consequences of service quality. J. Mark. 1996, 60, 31-46. [CrossRef]

58. Jin, N.P.; Lee, S.; Lee, H. The Effect of Experience Quality on Perceived Value, Satisfaction, Image and Behavioral Intention of Water Park Patrons: New versus Repeat Visitors. Int. J. Tour. Res. 2013, 17, 82-95. [CrossRef]

59. Netemeyer, R.G.; Bearden, W.O.; Sharma, S. Scaling Procedures: Issues and Applications. Sage Publications: Thousand Oaks, CA, USA, 2003.

60. Zhang, Y.; Xie, P.F. Motivational determinates of creative tourism: A case study of Albergue art space in Macau. Curr. Issues Tour. 2019, 22, 2538-2549. [CrossRef]

61. Anderson, J.C.; Gerbing, D.W. Structural equation modelling in practice: A review and recommended two-step approach. Psychol. Bull. 1988, 103, 411-423. [CrossRef]

62. Hair, J.F.; Black, W.C.; Babin, B.J.; Anderson, R.E. Multivariate Data Analysis, 7th ed.; Prentice-Hall: Upper Saddle River, NJ, USA, 2010.

63. Chin, W.W. Issues and opinions on structural equation modelling. MIS Q. 1998, 22, 7-16. [CrossRef]

64. Fornell, C.; Larcker, D.F. Evaluating structural equation models with unobservable variables and measurement error. J. Mark. Res. 1981, 18, 39-50. [CrossRef]

65. Rahman, K. “Wow! It's cool”: The meaning of coolness in marketing. Mark. Intell. Plan. 2013, 31, 620-638. [CrossRef]

66. Luna-Cortés, G.; López-Bonilla, J.M.; López-Bonilla, L.M. Self-congruity, social value, and the use of virtual social networks by generation $Y$ travelers. J. Travel Res. 2019, 58, 398-410. [CrossRef]

67. Jiang, Y.; Ramkissoon, H.; Mavondo, F.T.; Feng, S. Authenticity: The link between destination image and place attachment. J. Hosp. Mark. Manag. 2017, 26, 105-124. [CrossRef]

68. Tsai, C.T.; Wang, Y.C. Experiential value in branding food tourism. J. Destin. Mark. Manag. 2017, 6, 56-65. [CrossRef]

69. Lee, W.; Sung, H.; Suh, E.; Zhao, J. The effects of festival attendees' experiential values and satisfaction on re-visit intention to the destination: The case of a food and wine festival. Int. J. Contemp. Hosp. Manag. 2017, 29, 1005-1027. [CrossRef]

70. Wong, J.Y.; Li, T.H.; Chen, A.; Peng, N. The effects of trade show environments on visitors. Event Manag. 2017, 21, 665-683. [CrossRef]

71. Jang, S.; Namkung, Y. Perceived quality, emotions, and behavioral intentions: Application of an extended Mehrabian-Russell model to restaurants. J. Bus. Res. 2009, 62, 451-460. [CrossRef]

72. Preacher, K.J.; Hayes, A.F. SPSS and SAS procedures for estimating indirect effects in simple mediation models. Behav. Res. Methods Instrum. Comput. 2004, 36, 717-731. [CrossRef] [PubMed]

73. Cohen, E. Authenticity and commodification in tourism. Ann. Tour. Res. 1988, 15, 371-386. [CrossRef]

74. Kolar, T.; Zabkar, V. A consumer-based model of authenticity: An oxymoron or the foundation of cultural heritage marketing? Tour. Manag. 2010, 31, 652-664. [CrossRef]

75. Elliott, R.; Wattanasuwan, K. Brands as symbolic resources for the construction of identity. Int. J. Advertising 1998, 17, 131-144. [CrossRef]

76. Vengesayi, S. A conceptual model of tourism destination competitiveness and attractiveness. In Proceedings of the Australia and New Zealand Marketing Academy Conference, Adelaide, Australia, 1-3 December 2003; pp. 637-647.

77. Whitfield, J.; Webber, D.J. Which exhibition attributes create repeat visitation? Int. J. Hosp. Manag. 2011, 30, 439-447. [CrossRef]

78. Kirkup, N.; Sutherland, M. Exploring the relationships between motivation, attachment and loyalty within sport event tourism. Curr. Issues Tour. 2017, 20, 7-14. [CrossRef]

79. Halpenny, E.A.; Kulczycki, C.; Moghimehfar, F. Factors effecting destination and event loyalty: Examining the sustainability of a recurrent small-scale running event at Banff National Park. J. Sport Tour. 2016, 20, 233-262. [CrossRef]

80. Brown, G.; Smith, A.; Assaker, G. Revisiting the host city: An empirical examination of sport involvement, place attachment, event satisfaction and spectator intentions at the London Olympics. Tour. Manag. 2016, 55, 160-172. [CrossRef]

81. Jin, N.; Line, N.D.; Goh, B. Experiential value, relationship quality, and customer loyalty in full-service restaurants: The moderating role of gender. J. Hosp. Mark. Manag. 2013, 22, 679-700. [CrossRef] 